\title{
ILMU UKUR TANAH BAGI PERANGKAT DESA PANASEN KECAMATAN KAKAS BARAT KABUPATEN MINAHASA
}

\author{
Yessy Christiani Sophiane Pandeiroth \\ Prodi Pendidikan Teknik Bangunan, Fakultas Teknik, Universitas Negeri Manado (UNIMA) \\ yessypandeiroth@unima.ac.id
}

\begin{abstract}
The village map becomes a reference in the village development plan and supports the village budget acceleration policy. The village map will also assist the asset inventory, so it can be used as a management capital of the Village Owned Enterprise (BUMDes).

In Law 6/2014 on the Village it is clear that the boundaries of village areas are expressed in the form of village maps. The village map is the geospatial data and information that will be the basis for rural area development planning. With the existing village map, village officials can know the boundaries of the villages, identify and inventory the potential or assets of the village. Through the village map, also known what are the obstacles in the effort to empower the potential.

As a social society there are many problems that often arise among the community itself, as there is often a misunderstanding of the people against the boundaries and land / land ownership, it is due to lack of understanding of the people about the basic knowledge of the Soil Measure Science.

The training that has been carried out in relation to how to measure, calculate, map out the measurements and determine the boundaries of the soil and how to correctly use the land measurement tools provides expertise for the village apparatus.

Keywords: Soil measurement technique, village map, land border.
\end{abstract}

\section{PENDAHULUAN}

\section{Analisis Situasi}

Manusia memanfaatkan tanah sebagai sumber untuk hidup. Sehingga lahan di suatu daerah sesuai potensinya dimanfaatkan guna menyokong kehidupan sebagai contoh dimanfaatkan sebagai tempat tinggal, lahan pertanian, perdagangan dan aspek kegiatan sosial lainnya.

Adanya bukti kepemilikan tanah atau lahan yang resmi adalah hal yang sangat penting, guna menghindari terjadinya permasalahan atas kepemilikan atau sengketa tanah. Kebijakan pemerintah tentang landreform diantaranya menyangkut hal yang teknis berupa pengukuran dan pemetaan, dimana informasi ini akan dibakukan sebagai referensi status kepemilikan tanah atau lahan yang resmi (Novprastya et al, 2014)

Peta desa menjadi rujukan dalam rencana pembangunan desa serta mendukung kebijakan percepatan dana desa.Peta desa juga akan membantu upaya inventarisasi aset, sehingga dapat digunakan sebagai modal pengelolaan Badan Usaha Milik Desa (BUMDes). Peta desa penting untuk mempercepat pembangunan desa dalam mewujudkan Nawa Cita Presiden Joko Widodo, yakni membangun dari pinggiran. "Batas wilayah sangat diperlukan karena merupakan langkah awal untuk mengidentifikasi aset dan menginventarisasi aset yang dimiliki".

Dalam UU 6/2014 tentang Desa disebutkan jelas bahwa batas wilayah desa dinyatakan dalam bentuk peta desa. Peta 
desa merupakan data dan informasi geospasial yang akan menjadi dasar untuk perencanaan pembangunan wilayan perdesaan. Dengan adnaya peta desa, maka aparat desa dapat mengetahui batas wilayah desa, mengidentifikasi dan menginventarisasi potensi atau aset desa. Melalui peta desa, juga diketahui hal apa saja yang menjadi kendala dalam upaya pemberdayaan potensi tersebut.

"Peta desa bertujuan untuk mempercepat pembangunan desa dan kawasan pedesaan sekaligus sebagai upaya untuk meningkatkan kesejahteraan masyarakat." Tujuan adanya menggambar peta lahan di desa adalah mendorong partisipatif warga desa untuk menggambarkan tataletak unsur-unsur yang terdapat pada lahan garapan atau lahan tempat tinggal di atas sebuah media kertas sehigga masyarat secara luas akan mengetahui kondisi dan situasi yang actual lahan desanya. Dan selanjutnya peta tersebut dapat dijadikan alat bantu dalam perencanaan dan pengembangan produktivitas desa (USAID,2006)

Desa Panasen terletak di kecamatan kakas barat kabupaten minahasa Propinsi Sulawesi Utara, berada disekitar Danau Tondano dengan jumlah penduduk sekitar 1500 jiwa dengan sekitar 400 Kepala keluarga dan hampir 98 persen penduduknya berprofesi sebagai petani. Sektor pertanian menjadi tulung punggung perekonomian masyarakatnya, Profesi petani banyak dipilih karena ditunjung oleh ketersediaan sumber daya alam/lahan 90 pertanian yang subur dengan kontur tanah cenderung datar dan dikelilingi oleh perbukitan.

Desa Panasen berada di Wilayah Kecamatan Kakas Barat Kabupaten Minahasa. Jumlah penduduk 1350 jiwa yang tersebar pada lima Lingkungan yakni I, II, III. Jumlah Kepala Keluarga terdiri dari 374 Kepala keluarga yang tersebar pada Lingkungan I sampai dengan Lingkungan V masing-masing 64, 63, 66, 87, dan 94 Kepala Keluarga Sebagai suatu masyarakat sosial ada banyak masalah yang sering muncul diantara masyarakat itu sendiri, seperti sering terjadi kesalahpahaman masyarakat terhadap batas-batas dan luas lahan/kepemilikan tanah, hal tersebut terjadi karena : 1) Kurangnya pengetahuan akan teknik ukur tanah bagi perangkat desa panasen; 2) Tidak tersedianya peta desa yang sesuai dengan realitas di lapangan; 3) Cara pengukuran tanah oleh para perangkat desa masih kurang tepat; 4) Kurangnya pengetahuan sehubungan dengan cara menghitung luas tanah dengan bentuk sembarang; 5) Sering terjadi perselisihan antar warga sehubungan dengan batas tanah

Atas dasar masalah-masalah tersebut maka pemerintah desa panasen menyampaikan kepada pelaksana bahwa mereka sangat membutuhkan pelatihan dan pendampingan sehubungan dengan bagaimana cara mengukur, menghitung, membuat peta hasil pengukuran dan menentukan batas-batas tanah serta cara menggunakan alat-alat ukur tanah dengan 
benar dan teknik penghitungan luas tanah menggunakan aplikasi komputer.

\section{Metode Analisis Permasalahan}

Dari permasalahan yang dihadapi petani diatas maka metode penyelesaian yang digunakan adalah dengan beberapa pelatihan dan pendampingan berupa kegiatan yang terbagi menjadi dua bagian yaitu, Proses Pelatihan bagaimana cara menggunakan alat ukur, mengukur, menghitung, membuat peta, serta Pasca Pelatihan berupa pendampingan bagaimana perampungan peta wilayah desa dan batasbatas lahan secara komplit.

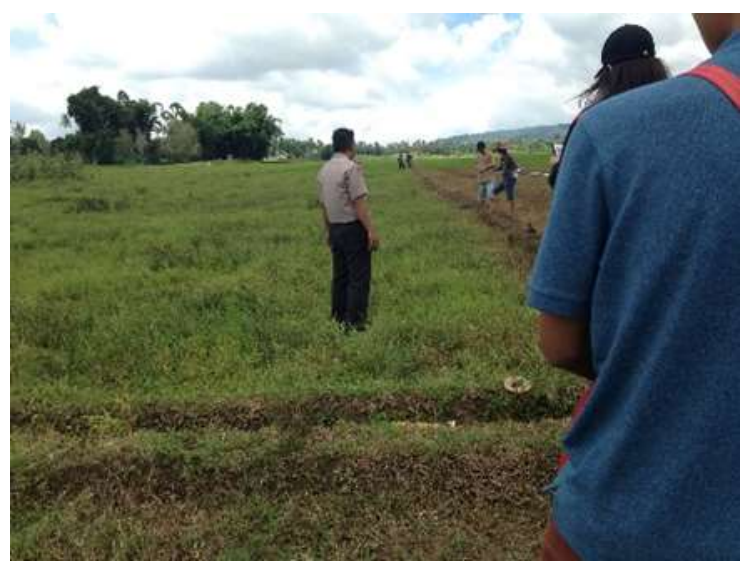

Gambar 1. Konflik masalah batas lahan.

Adapun luaran dari kegiatan ini adalah sebagai berikut:

1) Kemampuan sehubungan dengan teknik ukur tanah bagi perangkat desa panasen;

2) Tersedianya peta desa yang sesuai dengan realitas di lapangan;

3) Kemampuan perangkat desa sehubungan dengan cara menghitung luas tanah dengan bentuk sembarang;
4) Menurunya perselisihan antar warga sehubungan dengan batas tanah.

$$
\text { Berdasarkan permasalahan dan }
$$
solusinya maka luaran yang dihasilkan secara nyata dan terukur adalah Kemampuan sehubungan dengan teknik ukur tanah bagi perangkat desa panasen; Tersedianya peta desa yang sesuai dengan realitas di lapangan; Kemampuan perangkat desa sehubungan dengan cara menghitung luas tanah dengan bentuk sembarang; Menurunya perselisihan antar warga sehubungan dengan batas tanah. Serta Jurnal ilmiah Nasional.

\section{METODE PELAKSANAAN}

Metode pendekatan dalam pengabdian ini adalah metode praktik/ demonstrasi yaitu dengan memberikan materi pendidikan baik menggunakan alat atau benda, seperti di peragakan, dengan harapan peserta pelatihan menjadi jelas dan mudah sekaligus dapat mempraktikkan materi yang di maksud suatu saat di lapangan.

Metode ini memberikan jalan kepada peserta pelatihan untuk menerapkan, menguji dan menyesuaikan teori dengan kondisi sesungguhnya melalui praktik peserta praktik atau latihan akan mendapatkan pelajaran yang sangat baik untuk mengembangkan dan menyempurnakan keterampilan yang di perlukan.

Model pembelajaran praktik atau pelatihan ini terdiri dari enam tahap diantaranya: 
1) Penyampaian tujuan. Langkah awal dari urutan pembelajaran praktik adalah merumuskan dan menyampaian tujuan yang ingin di capai dalam proses pelatihan. Tujuan dirumuskan seoperasional mungkin sehingga tujuan belajar peserta pelatihan dapat di ukur, dalam arti seberapa jauh tujuan pembelajaran telah dicapai.;

2) Penjelasan materi praktik. Materi pendukung praktik dengan menggunakan metode ceramah. Agar metode ceramah lebih bermakna dan menarik perhatian peserta pelatihan, beberapa materi pembelajaran praktik di sajikan melalui media audio visual;

3) Pendemonstrasian cara kerja. Menunjukan cara menggunakan alat ukur serta taahapan pengukuran yang benar kepada peserta pelatihan dengan menggunakan peragaan;

4) Latihan (Praktik Simulasi). Ketuntasan dari beberapa tujuan keterampilan memerlukan latihan (praktik). Praktek yang dilakukan secara kontinu untuk menghasilkan kesempurnaan keterampilan motorik. peserta pelatihan melakukan latihan dengan tugas yang diberikan dengan tujuan untuk mengembangkan dan mendemonstrasikan keterampilan. kegiatan praktik memungkinkan peserta pelatihan untuk lebih efektif terlibat dalam kegiatan belajar. Guna mengoptimalkan proses pembelajaran dalam tahap praktik melalui Persiapan praktik, dan Pelaksanaan praktik ;
5) Latihan pengalihan. Pengalihan adalah pengunaan hal-hal yang telah dipelajari untuk menghadapi atau memecahkan hal-hal baru. Latihan pengalihan dilaksanakan agar apa yang telah dipelajari dapat digunakan untuk berbagai bentuk kondisi bidang tanah.

Pemerintah desa berpartisipasi dalam bentuk:

1) Menyediakan fasilitas tempat untuk pelatihan dan produksi

2) Menyediakan peserta pelatihan

3) Bertanggung jawab untuk mengikuti pelatihan

4) Bertanggung jawab untuk menjaga dan merawat peralatan yang diberikan pihak pertama

5) Bertanggung jawab untuk membuat peta desa secara keeseluruhan.

\section{Evaluasi Pelaksanaan kegiatan}

\section{berkelanjutan}

Melakukan monitoring dan evaluasi terhadap bagaimana pengalaman dan penerapan metode/Teknik pengukuran yang dilaksanakan oleh pemerintah desa dalam hal ini aparat desa Panasen dan sejauh mana keahlian yang telah diberikan dimanfaatkan dan bisa membantu apparat desa dalam mempermudah proses pengukuran, perhitungan, pemetaan dan penentuan batas-batas lahan yang benar.

\section{HASIL DAN PEMBAHASAN}

Kegiatan pelatihan perancangan Media pembelajaran melibatkan seluruh Gene- 
rasi muda yang ada didesa Passo Kecamatan Kakas. Kegiatan ini telah dilaksanakan bertempat di rumah keluarga Sumayku-Rakian dan diikuti oleh Generasi muda yang ada didesa Passo Kecamatan Kakas. Metode yang digunakan dalam kegiatan penyuluhan yang dilaksanakan relevan dengan pokok permasalahan yang disesuaikan dengan tujuan yang ingin dicapai adalah yaitu metode presentasi, tanya jawab, demonstrasi dan pemberian tugas.

Pelaksanan pelatihan bahasa Jepang bagi pada Generasi muda yang ada didesa Passo Kecamatan Kakas hasilnya sebagai berikut:

1. Adanya respon positif baik dengan dari pemerintah maupun dari masyarakat. Ini ditandai dengan turut hadirnya unsur pemerintah dan LPM desa Passo kecamatan Kakas

2. Animo peserta baik pemuda dan remaja yang sangat antusias dan penuh kesungguhan dalam mengikuti pelatihan ini.

3. Peserta sudah mengetahuidan dapat menggunakan ungkapan-ungkapan persalaman, bentuk-bentuk kalimat percakapan praktis dalam bahasa Jepang.

Dari hasil evaluasi serta respon positif sebagaimana yang diungkapkan diatas maka dapatlah dikemukakkan berbagai hal sebagai berikut:

1. Pelatihan bahasa kepada pemuda dan Remaja merupakan suatu kegiatan yang cukup baik dan efektif karena dapat membekali peserta dengan pengetahuan dan kemampuan untuk berkomunikasi.

2. Meningkatkan rasa percaya diri terutama bagi pemuda dan remaja terutama bagi mereka yang tingkat pendidikannya rendah.

3. Dengan adanya kemampuan komunikasi bahasa Jepang yang sederhana akan tercipta komunikasi yang baik dengan wisatawan Jepang. Keadaan ini juga turut membantu menyukseskan Manado sebagai kota pariwisata Dunia (MKPD) tahun 2020.

\section{KESIMPULAN DAN SARAN}

\section{Kesimpulan}

1. Kegiatan pengabdian pada masyarakat dalam bentuk pelatihan bahasa Jepang praktis pada Generasi muda yang ada didesa Passo Kecamatan Kakas telah berhasil dilaksanakan dengan baik.

2. Pelaksanaan pelatihan ini telah mencapai tujuan yang dilaksanakan karena semua peserta dapat menguasai dan menggunakan bahasa Jepang sederhana.

\section{Saran}

Dengan melihat keberhasilan yang diperoleh serta animo masyarakat/peserta maka disarankan agar kegiatan pengabdian pada masyarakat dalam bentuk pelatihan berupa kusus singkat seperti ini perlu ditindak lanjuti pada lokasi yang sama maupun lokasi yang lain dengan topic/materi yang sama (Bahasa Jepang) 
Jurnal ABDIMAS, Vol. 11, No. 1, April 2018

ISSN: 1979-0953 | e-ISSN: 2598-6066

ataupun bahasa Asing lainya. Mengapa

dikatakan demikian karena wisatawan

mancanegara yang nantinya akan

berkunjung kemanado sangat beragam.

\section{KEPUSTAKAAN}

Sudjono, Anas. 1996. Pengantar Evaluasi Pendidikan. Jakarta: PT.Rajagrafindo Persada

Syaodih Sukmadinata, Nana. 2006. Metode Penelitian

Bandung:
Program Pascasarjana UPI \& PT. Remaja Rosdakarya

Suzuki,S dan kawase. 1979. Nihongo Shoho. Japan: The Japan Foundation

Tarigan. 1987. Teknik Pengajaran Keterampilan Berbahasa. Bandung : Angkasa

Trihendradi, Cornelius. 2005. Step by Step SPSS $13 \quad$ Analisis Data Statistik.Yogyakarta:Andi Ofset

Widodo, Edi. 2006. Multimedia dan Pembelajaran Bahasa. Bandung. 